\title{
The impact of innovation and the use of ICTs on human capital development in Spanish industry
}

\author{
Josep-Maria Batalla-Busquets ${ }^{1}$, Vasileios Myrthianos $^{2}$ \\ ${ }^{1}$ Universitat Oberta de Catalunya (Spain) \\ ${ }^{2}$ Universtitat Politècnica de Catalunya (UPC) (Spain) \\ jbatalla@uoc.edu,vvmyrthianos@gmail.com
}

Received May, 2013

Accepted March, 2015

\section{Abstract}

Purpose: The analysis of the characteristics of the industrial companies that invest in the training of their human capital in comparison to the organizations that do not train their employees. This characterization is focused especially on the innovative capacity of firms and their technological applications. It also analyzes the factors that determine the likelihood that a company invests in personnel training.

Design/methodology/approach: Descriptive characterization of those companies that invest in personnel training, comparing them against those who do not invest in improving its human capital. Furthermore, factors influencing the decision that a company invest in training are analyzed through a logistic regression. Among them we included the intensity of technological usage and the innovation capacity. This research is based on data from the Survey of Business Strategies (ESEE) in 2009, conducted annually. The sample is approximately 1,800 companies, being representative of the Spanish manufacturing sector.

Findings: Companies with a higher likelihood of investing in training of their workers are those with a larger number of workers, a higher level of qualification of employees, more stable labor relations, greater participation foreign capital, and also, have a higher level of technological uses, carries more technological partnerships with other organizations and has a more intense innovative activity. 
Social implications: In the current situation of job destruction and lack of competitiveness of the Spanish industry in increasingly globalized markets, training of workers is seen as the main alternative to increase the productivity of the Spanish industry. This study shows that the industrial structure does not meet the basic conditions described in the scientific literature, in order the companies to train their workers with the risk of exclusion that entails.

Originality/value: The study of the characteristics of Spanish companies that invest in training, and the factors that influence the likelihood of this investment, using recent data (2009) with high statistical consistency. There are still few studies that analyze the improvement of human capital in Spain in the current period of economic crisis.

Keywords: Lifelong learning, Workplace learning, ICT, Innovation

Jel Codes: I21, J24, M21

\section{Introduction}

In the last few decades, human capital development has become a key factor in the competitiveness of companies (Monreal, 2004; Jeon \& Kim, 2012) for two main reasons. Firstly, the large-scale incorporation of information and communication technologies (ICTs) into business activity means that new skills are required for work, as well as new ways of working and establishing relationships (Bresnahan, Brynjolfsson \& Hitt, 2002). Secondly, an increase in the economic use of knowledge (Haelermans \& Borghans, 2012) has led to a major change in the conditions and characteristics of the labour market (Carnoy, 2001).

These two processes have brought about a general increase in the need for continuing vocational training (CVT). All training activities carried out by companies, employees or the corresponding representative organizations must be aimed at improving the professional skills and qualifications of working professionals, so that they can meet the needs of a changing, digitalized, global labour market (Castells, 2003). In fact, most authors (including Johnson, 1982; Piore \& Sabel, 1984; Pfeffer, 1998) consider that the most efficient way of increasing company flexibility is through employee-centred organizational innovations that involve intensive training, boost productivity, and give workers a feeling of security and of belonging to a team (Carnoy, 2001). In short, increases in productivity depend not only on investment in technology, but also on organizational changes and skilled human resources, which are 
required to extract and benefit fully from the technological potential (Brynjolfsson \& Hitt, 2003).

Therefore, learning is important mainly because of the need for organizations to respond to constant, rapid changes in the surrounding environment (Coetzer \& Perry, 2008). To train employees, a learning environment is required that enables them to advance professionally and to gain new general and specific skills and abilities (Fan \& Wei, 2010). To achieve this, employees may train in an environment either outside or within an organization. The learning environment that is most closely associated with real work experience is training in the workplace (Fan \& Wei, 2010).

The report entitled Learning for Jobs, published by the OECD (2010), presents the four main advantages of workplace or internal training. Specifically, continuing education in the workplace provides a high quality learning environment that enables students-employees to gain practical, up-to-date knowledge under trainers or tutors who are familiar with the working method and the use of technologies. Secondly, workplace training facilitates a two-way flow of information between potential employers and employees, which makes the subsequent process of recruitment easier, less costly and more effective. Thirdly, employees who are trained in the workplace can make a productive contribution to the company. Finally, the fact that companies train their employees for their professional tasks shows the value of vocational training programmes in the labour market. This last point is particularly relevant in Spain, given the specific distribution of educational levels in the population. Specifically, Figure 1 shows the main problem with human capital in Spain: the lack of professionals with an intermediate-level of training. Only $22 \%$ of Spain's adult population have completed secondary and/or postsecondary non-higher education. In the European Union, this figure stands at $48 \%$, which is over twice as high. The challenge for human capital in Spain is to improve the training of the $46 \%$ of the population who have only completed primary education.

The considerable gap between the level of secondary studies in Spain and in surrounding countries (EU-21) is due mainly to two factors:

- the high rate of school failure in secondary schools, which leads to withdrawal from vocational and general training, and

- the low reputation of vocational training in our education system (Ministerio De Educación, Cultura Y Deportes, 2013). 


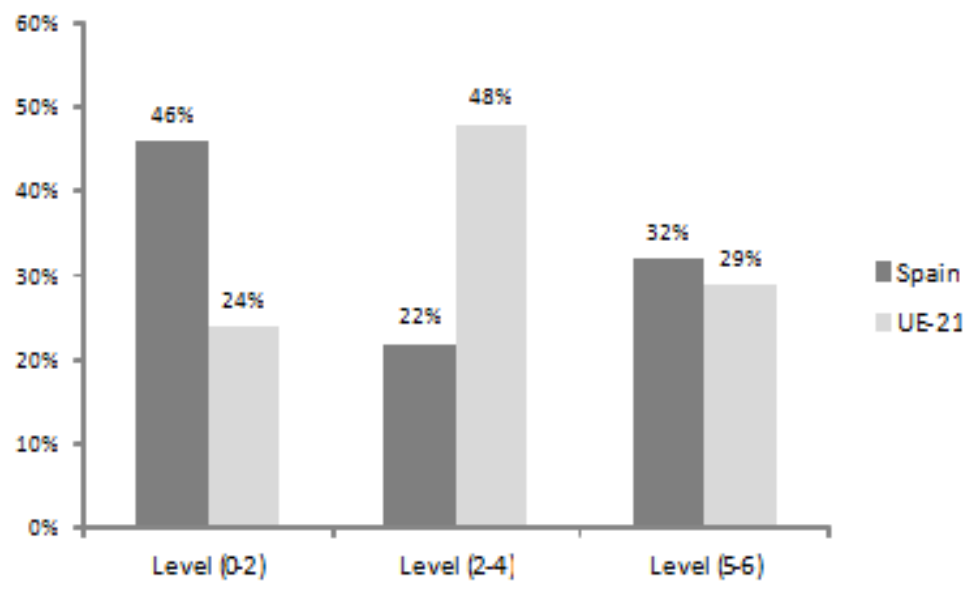

Level (0-2): preschool, primary and the first stage of secondary education

Level (3-4): second stage of secondary education and post-secondary non-higher education

Level (5-6): first and second cycle of higher education and doctoral programmes

Source: OECD indicators

Figure 1. Level of education in the adult population (25-64 years). Spain and the EU-21. 2011

In turn, the massive injection of knowledge into the economy has an impact on management, production and working methods. It makes employment relationships more flexible, either voluntarily or involuntarily, which forces companies to accept that process and product innovation is of great value to them, as is a continuous process of retraining. This constant involvement with knowledge, updating it, and continuous learning again favours the use of workplace training as an essential method to ensure a perfect symbiosis of work and training (Batalla-Busquets, Martínez-Argüelles \& Vilaseca, 2010).

In the current climate of job destruction and a lack of competitiveness of Spanish industry in increasingly globalized markets, this study aims to analyse and explore the potential of training as a tool to boost business success. In fact, it is increasingly clear that the main way to increase work productivity in Spain is to improve employees' skills and abilities, in other words, increase investment in the continuous development of human capital.

Below, we describe the theoretical framework of the research, and present the sources of information used. After that, we describe the main results obtained in the study and, finally, we discuss the main conclusions and limitations. 


\section{Theoretical framework}

The concept of human capital (Schultz, 1961) and its subsequent consolidation in the Theory of Human Capital (Becker, 1964) form a corpus of theory that explains the positive impact of investing in employee training. Basically, better qualified employees will have gained new skills and abilities that enable them to be more productive in their work. The increase in productivity is reflected in higher salaries (de Grip \& Sauermann, 2013). At the same time as this formulation, the first empirical studies emerged on the factors that determine the existence of training processes in companies. The seminal work of Mincer and Polachek (1974) analysed the decision-making process in families from a gender perspective, and in terms of human capital investment. After this, the first scientific studies were published on the existence of a pattern explaining how investment in staff training is distributed (Duncan \& Hoffman, 1979; Greenhalgh \& Stewart, 1987).

The results of the numerous empirical studies that use sources of business information are focused mainly on describing the attributes of companies that invest in developing the human capital of their professional team. At international level, some studies show that there is a positive relationship between the probability of receiving training and the size of the company, expressed in terms of the number of workers (Hashimoto, 1979; Oi, 1983; Holtmann \& Idson, 1991; Barron, Black \& Loewenstein, 1987; Lynch, 1994). Others highlight the academic experience of the employees themselves (for example, Altonji \& Spletzer, 1991; Lynch \& Black, 1995; Bishop, 1996; Harris, 1999), the type of contract (Oosterbeek, 1996), the salary level (Barron et al., 1987; Lynch, 1992; Bishop, 1994), or the unionization of employees (Arulampalam \& Booth, 1998; Jonker \& de Grip, 1999), among other corporate factors. In Spain, despite the lack of availability of data, which has limited the number of studies in this area (Peraita, 2000), we can find many studies with this focus, such as those of Abellán, Felgueroso and Lorences (1997), Crespo and Sanz (2000), Diéguez and Sinde (2004), Albert, García-Serrano and Hernanz (2005), Caparrós, Navarro and Rueda (2005), Vila and GarcíaMora (2005), Escardíbul, Oroval and Afcha (2007), García-Moreno, Guerras and Rico (2007), Pineda Herrero (2007) and Castany (2008).

The increasing interest in training is shown by the increase in public and private investment in improving the qualification of human capital (Peraita, 2000; García-Delgado, 2003; Pineda Herrero, 2007). In recent years, there has been a significant, sustained rise in the number of companies that provide training for their employees, and in the specific proportion of the cost of continuing training in total labour costs. This increase in investment reflects the importance given to the training and retraining of people as a key factor to increase work productivity 
(Monreal, 2004). In addition, many employees take training courses and cover the costs themselves.

However, a high percentage of companies still do not consider employee training to be a key factor in maintaining and increasing competitiveness. This is particularly true in small and, to some extent, medium-sized companies, due to a lack of knowledge about public funds for promoting corporate training (Pineda Herrero, 2007).

In terms of public investment, the funds allocated to continuing training have been increased and the funding structure has changed. For example, corporate training was boosted by the coming into force of Royal Decree 395/2007, in which the responsibility for employee training was attributed to the companies themselves. These public funds are managed by the Fundación Tripartita. This kind of training is a more flexible, effective way to respond to the diversity and frequent changes in employee training needs. Thus, in the 2006-2012 period, the percentage of companies who benefited from these funds rose from $5.8 \%$ to $31.1 \%$ (Fundación Tripartita, 2012).

Nevertheless, a substantial proportion of the funds that the administration makes available to companies to fund employee training does not end up being used. In 2012, Spanish companies used only just over $30 \%$ of the total funds available for this kind of training (Fundación Tripartita, 2012). Therefore, the focus of interest of this study is to analyse the characteristics of companies that train employees and the determining factors in corporate training, to explain the gap between organizations that invest in training and those that do not.

\section{Data and methods}

To carry out this research, we used a cross-sectional sample for 2009 of 2,132 Spanish manufacturing companies from the Business Strategy Survey (ESEE) carried out by the Fundación Empresa Pública (FUNEP). This survey gathers unbalanced panel data for the 19902010 period on companies' strategic decisions and behaviour. Every four years, companies answer a full questionnaire (whose questions are supposed to remain the same each year). In the intermediate years, the companies answer a short questionnaire. As a result, complete information is available for 1990, 1994, 1998, 2002 and 2006. The ESEE survey population is companies with 10 or more employees dedicated to one of the activities corresponding to Divisions 10 to 33 of the CNAE-2009 classification, excluding Division 19 (activities related to oil refining and fuel handing, except nuclear fuel). The survey contains information about the general characteristics of companies, their employees, the organization, the business strategy, the equipment and uses of ICTs and innovation, among other aspects. 


\section{Descriptive analysis}

To understand the situation under study, we first needed to characterize the Spanish industrial sector. The description was based on the results obtained by applying an analysis of variance (ANOVA), in which aspects related to employee training were central to the study. The characterization is divided into two blocks. The first includes variables that are validated in the scientific literature as determining factors in corporate training, such as company size (Holtmann \& Idson, 1991; Black, Noel \& Wang, 1999; Crespo \& Sanz, 2000; Caparrós et al., 2005); the type of employment relationships (García-Espejo, 1999; Planas \& Passard, 2000; Tugores \& Alba-Ramírez, 2002; Caparrós, Navarro \& Rueda, 2004; Castany, 2008), the sector (Harris, 1999; García Moreno et al., 2007; Turcotte, Léonard \& Montmarquette, 2003), the foreign capital investment (Alba-Ramírez, 1994), level of training of employees (Peraita, 2000; García Moreno et al., 2007), among other variables. The second block provides a more detailed analysis of research and development activities, innovation, and technology uses, to validate the association between the existence of innovative activity in a company and corporate investment in human capital development, as stated by Alba-Ramírez (1994) or García Moreno et al. (2007) for the Spanish economy.

Table 1 presents the frequencies in the survey sample, which was divided into four business categories: no training, training by the company, some training outsourced, all training outsourced.

\begin{tabular}{|l|r|r|r|}
\hline \multicolumn{1}{|c|}{ Companies } & Frequency & Percentage & \multicolumn{1}{c|}{ Cumulative percentage } \\
\hline No training & 212 & $9.9 \%$ & $9.9 \%$ \\
\hline Training by the company & 905 & $42.4 \%$ & $52.4 \%$ \\
\hline Some training outsourced & 771 & $36.2 \%$ & $88.6 \%$ \\
\hline All training outsourced & 244 & $11.4 \%$ & $100 \%$ \\
\hline Total & 2,132 & $100 \%$ & $100 \%$ \\
\hline
\end{tabular}

Table 1. Frequencies in the sample of companies (ESEE data)

If we add together all companies that stated they train their employees, $90.1 \%$ of companies considered that they had undertaken some training for their employees in the last financial year, and $9.9 \%$ did not allocate any resources to the development of their human capital.

In this study, we found statistically significant differences between the two main kinds of companies that were analysed, depending on whether or not training was carried out in them (see Table 2). 
Companies in the Spanish industrial sector that do not invest in employee training are mainly micro-enterprises: $71 \%$ have fewer than 20 employees, and $91.6 \%$ fewer than 50 employees. The intensity of knowledge use is mainly low; specifically $86 \%$ of these companies are in sectors with low knowledge intensity. Foreign capital investment is practically non-existent, and the percentage of export companies is $31.6 \%$; half that of companies that train employees. The proportion of temporary and permanent staff is similar to the average for Spanish industry. Frankly, the level of training of employees could be improved, as only $6.69 \%$ have a university qualification at intermediate or higher level. The database does not provide more detailed information about the level of non-university training of employees who do not have a university qualification (93.31\%).

Finally, the productivity of employees, measured using gross value added (GVA), is 57\% in companies that provide training. GVA is calculated using the average number of total staff (ATS), which is calculated as the sum of the following concepts: Full-time permanent staff, 1/2 of part-time permanent staff (both concepts on 31 December) and the average number of temporary staff.

Industrial companies that train their employees are larger: 52\% have over 50 employees. Almost all of the medium-sized and large companies (with over 200 employees) train for their employees. A quarter of them carry out industrial activity in sectors with high knowledge intensity. To determine this figure, a dichotomous variable was used to indicate whether or not a company offered a knowledge-intensive service. The classification of companies by knowledge intensity was initially carried out according to OECD proposals (1999).

The percentage of companies with foreign capital investment was $16.5 \%$, and two thirds of companies that train employees were exporters. The level of qualification of employees was much higher in companies that offer training than in companies that do not: almost $14 \%$ of employees had a university qualification at intermediate or higher level. In our sample, the average productivity of companies that offer training was 50,000 euros per employee, whilst the average productivity per employee in companies that do not offer training was 29,000 euros. This difference of just over 20,000 euros is statistically significant.

Below, we analyse the differences in research and development activities, technology planning, innovative activity, intensity of Internet use, and specific research and development jobs among companies that invest in training and those that do not make this investment. In the comparative analysis of research and development activities (see Table 3), we found that companies that train employees undertake more activities associated with research and development (38.3\%). These activities are practically non-existent in companies that do not train employees. In addition, although technology collaborations do not take place in anywhere 
near the majority of companies, organizations that develop their human capital establish more collaborations with universities and research centres, and with suppliers and clients. These kind of collaborations are extremely rate in companies that do not train employees.

\begin{tabular}{|c|c|c|c|}
\hline$\%$ Companies & $\begin{array}{l}\text { Companies that } \\
\text { offer training }\end{array}$ & $\begin{array}{l}\text { Companies that do } \\
\text { not offer training }\end{array}$ & Hypothesis testing \\
\hline Company size (TEMPRE) & $\begin{array}{r}52 \%>50 \\
\text { employees }\end{array}$ & $8.4 \%>50$ employees & $\begin{array}{r}x^{2}=149,317 \\
\operatorname{Sig}=0,000\end{array}$ \\
\hline $\begin{array}{l}\text { Average total number of } \\
\text { staff (PERTOT) }\end{array}$ & 217.48 & 33.87 & $\begin{array}{r}F=15,829 \\
p=0,000\end{array}$ \\
\hline $\begin{array}{l}\text { Average number of } \\
\text { establishments (NTES) }\end{array}$ & 1.65 & 1.26 & $\begin{array}{r}F=10,488 \\
p=0,001\end{array}$ \\
\hline Knowledge intensity (IC) & $\begin{array}{l}72.5 \% \text { low IC } \\
27.5 \% \text { high IC }\end{array}$ & $\begin{array}{r}86.1 \% \text { low IC } \\
13.9 \% \text { high IC }\end{array}$ & $\begin{array}{l}X^{2}=17,282 \\
\text { Sig }=0,000\end{array}$ \\
\hline $\begin{array}{l}\text { Foreign capital investment } \\
\text { (PCAEXT) }\end{array}$ & $16.5 \%$ & $1.4 \%$ & $\begin{array}{r}F=26,302 \\
p=0,000\end{array}$ \\
\hline Exportation (EXPORT) & $67.7 \%$ & $31.6 \%$ & $\begin{array}{l}x^{2}=79,388 \\
\text { Sig }=0,000\end{array}$ \\
\hline $\begin{array}{l}\text { Proportion of full-time } \\
\text { permanent staff (PFTC) }\end{array}$ & $96.67 \%$ & $93.92 \%$ & $\begin{array}{r}F=13,192 \\
p=0,000\end{array}$ \\
\hline $\begin{array}{l}\text { Proportion of part-time } \\
\text { permanent staff (PFTP) }\end{array}$ & $3.19 \%$ & $5.44 \%$ & $\begin{array}{r}F=11,034 \\
p=0,001\end{array}$ \\
\hline $\begin{array}{l}\text { Proportion of temporary } \\
\text { staff (PEVEN) }\end{array}$ & $8.6 \%$ & $7.7 \%$ & $\begin{array}{r}F=41,128 \\
p=0,000\end{array}$ \\
\hline $\begin{array}{l}\text { Proportion of engineers } \\
\text { and degree holders (PIL) }\end{array}$ & $6.34 \%$ & $2.59 \%$ & $\begin{array}{r}F=32,997 \\
p=0,000\end{array}$ \\
\hline $\begin{array}{l}\text { Proportion of holders of } \\
\text { intermediate level } \\
\text { qualifications (PTIM) }\end{array}$ & $7.29 \%$ & $4.1 \%$ & $\begin{array}{r}F=42,756 \\
p=0,000\end{array}$ \\
\hline $\begin{array}{l}\text { Proportion of unqualified } \\
\text { staff (PNT) }\end{array}$ & $86.36 \%$ & $93.31 \%$ & $\begin{array}{r}F=39,102 \\
p=0,000\end{array}$ \\
\hline $\begin{array}{l}\text { Productivity per employee } \\
\text { (added value) (PRTP) }\end{array}$ & $50,250 €$ & $29,130 €$ & $\begin{array}{r}F=31,036 \\
p=0,000\end{array}$ \\
\hline
\end{tabular}

Table 2. Comparative analysis of the characteristics of companies that train employees and those that do not invest in training

Technology planning in Spanish companies, and more specifically in the industrial sector, is an area that is still in its infancy (see Table 4). Approximately a quarter of companies that provide training have a technology committee or assess perspectives of change or alternative technologies. In contrast, in organizations that do not invest in continuing vocational training, this planning is negligible: only $2 \%$ to $8 \%$ of companies in this group carry out some technology planning activities.

The decrease in productivity in the Spanish industrial sector since the start of the twenty-first century is related to a reduction in corporate investment in technology activities and a decrease in the ability of companies to turn their investments into product and process innovation in particular (Huergo \& Moreno, 2004). In fact, Table 5 shows that product and 
process innovations only occur in a small percentage of companies that train employees, and are non-existent in companies that do not invest in training. Just as worrying as these data is the lack of planning and assessment of innovation results.

\begin{tabular}{|l|r|r|r|}
\hline \multicolumn{1}{|c|}{$\%$ Companies } & $\begin{array}{l}\text { Companies that } \\
\text { offer training }\end{array}$ & $\begin{array}{l}\text { Companies that } \\
\text { do not training }\end{array}$ & Hypothesis testing \\
\hline $\begin{array}{l}\text { Research and } \\
\text { development activities }\end{array}$ & $38.3 \%$ & $5 \%$ & $\begin{array}{r}x^{2}=68,018 \\
\text { Sig }=0,000\end{array}$ \\
\hline $\begin{array}{l}\text { Technology collaboration } \\
\text { with clients }\end{array}$ & $19 \%$ & $2.6 \%$ & $\begin{array}{r}x^{2}=26,115 \\
\text { Sig }=0,000\end{array}$ \\
\hline $\begin{array}{l}\text { Technology collaboration } \\
\text { with suppliers }\end{array}$ & $21.3 \%$ & $3.2 \%$ & $\begin{array}{r}x^{2}=29,201 \\
\text { Sig }=0,000\end{array}$ \\
\hline $\begin{array}{l}\text { Technology collaboration } \\
\text { with universities and } \\
\text { technology centres }\end{array}$ & $25.7 \%$ & $2.6 \%$ & $x^{2}=41,727$ \\
\hline
\end{tabular}

Table 3. Research and development activities and technology collaboration Companies that train employees compared to those that do not invest in training

\begin{tabular}{|l|r|r|r|}
\hline \multicolumn{1}{|c|}{$\%$ Companies } & $\begin{array}{l}\text { Companies that } \\
\text { offer training }\end{array}$ & $\begin{array}{c}\text { Companies that do } \\
\text { not offer training }\end{array}$ & Hypothesis testing \\
\hline $\begin{array}{l}\text { Has technology management } \\
\text { or a technology committee }\end{array}$ & $24 \%$ & $2.6 \%$ & $\begin{array}{r}X^{2}=37,301 \\
\text { Sig }=0,000\end{array}$ \\
\hline $\begin{array}{l}\text { Assesses perspectives of } \\
\text { technology change }\end{array}$ & $29 \%$ & $6 \%$ & $\begin{array}{r}X^{2}=47,812 \\
\text { Sig }=0,000\end{array}$ \\
\hline $\begin{array}{l}\text { Assesses alternative } \\
\text { technologies }\end{array}$ & $28 \%$ & $8.4 \%$ & $\begin{array}{r}x^{2}=27,636 \\
\text { Sig }=0,000\end{array}$ \\
\hline $\begin{array}{l}\text { Uses consultants to find out } \\
\text { about technology }\end{array}$ & $22.3 \%$ & $8.4 \%$ & $\begin{array}{r}X^{2}=16,477 \\
\text { Sig }=0,000\end{array}$ \\
\hline
\end{tabular}

Table 4. Technology planning. Companies that train employees compared to those that do not invest in training

The differences between the two kinds of companies analysed in this study are statistically significant. Consequently, we decided to transform all of the variables related to product and process innovation into a dichotomous variable (INNOVEMPR) that is zero if the company does not innovate and one if the company undertakes some kind of product and/or process innovation. Figure 2 shows the difference between the two kinds of company and illustrates the statistically significant differences in the dichotomous variable between them. Individual hypothesis testing confirms the existence of significant differences. 


\begin{tabular}{|c|r|r|r|}
\hline$\%$ Companies & $\begin{array}{c}\text { Companies that } \\
\text { offer training }\end{array}$ & $\begin{array}{c}\text { Companies that do } \\
\text { not offer training }\end{array}$ & $\begin{array}{c}\text { Hypothesis } \\
\text { testing }\end{array}$ \\
\hline Obtain product innovations (IP): & $20.7 \%$ & $2.0 \%$ & $\begin{array}{c}X^{2}=32,194 \\
\text { Sig=0,000 }\end{array}$ \\
\hline IP. for new components & $13.6 \%$ & $1.9 \%$ & $\begin{array}{c}X^{2}=32,317 \\
\text { Sig=0,000 }\end{array}$ \\
\hline IP. for new functions & $13.8 \%$ & $1.9 \%$ & $\begin{array}{c}X^{2}=32,312 \\
\text { Sig=0,000 }\end{array}$ \\
\hline IP. for new materials & $13.2 \%$ & $1.9 \%$ & $\begin{array}{c}X^{2}=32,335 \\
\text { Sig=0,000 }\end{array}$ \\
\hline Obtain process innovations (IPr): & $32.7 \%$ & $11.6 \%$ & $\begin{array}{c}X^{2}=29,301 \\
\text { Sig=0,000 }\end{array}$ \\
\hline IPr. for new equipment & $23.0 \%$ & $9.0 \%$ & $\begin{array}{c}X^{2}=16,166 \\
\text { Sig=0,000 }\end{array}$ \\
\hline IPr. for new IT programmes & $15.6 \%$ & $5.8 \%$ & $\begin{array}{c}X^{2}=10,815 \\
\text { Sig=0,000 }\end{array}$ \\
\hline IPr. for new techniques & $19.7 \%$ & $5.8 \%$ & $\begin{array}{c}X^{2}=17,989 \\
\text { Sig=0,000 }\end{array}$ \\
\hline Has indicators of innovation results & $19.4 \%$ & $4.5 \%$ & $\begin{array}{c}X^{2}=21,066 \\
\text { Sig=0,000 }\end{array}$ \\
\hline Plans innovation activities & $24.7 \%$ & $3.0 \%$ & $\begin{array}{c}X^{2}=36,918 \\
\text { Sig=0,000 }\end{array}$ \\
\hline
\end{tabular}

Table 5. Innovative activity. Companies that train employees compared to those that do not invest in training

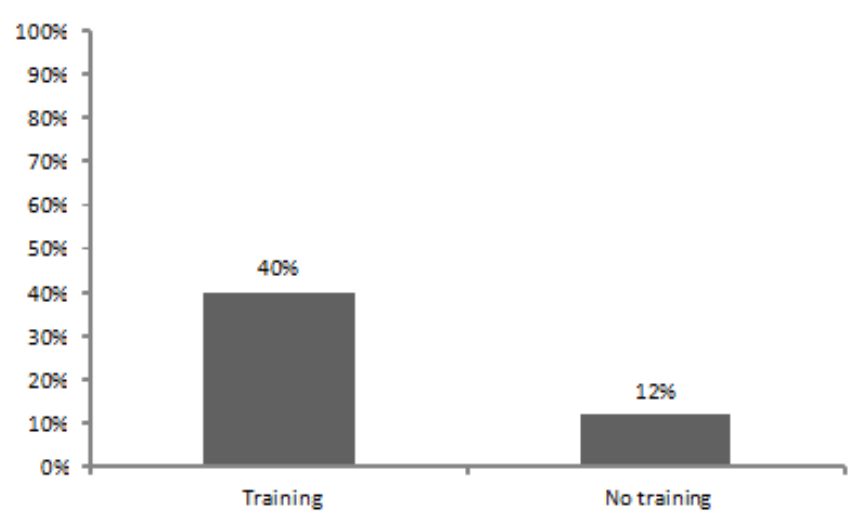

Figure 2. Innovation in the product and/or process. Training vs. no training

The Internet is widely used by companies in the Spanish industrial sector. However, the degree of penetration in the company's value chain is mostly low or non-existent. Almost $80 \%$ of companies have a website, but only $10 \%$ use this digital infrastructure as a sales platform. If we analyse the differences between companies that train employees and those that do not invest in training (see Table 6), we can see that most organizations that train employees have a website $(81 \%)$, compared to $61 \%$ of companies that do not offer training. In addition, more sophisticated uses of the Internet are found in higher proportions in companies that train their employees. 


\begin{tabular}{|l|r|r|r|}
\hline \multicolumn{1}{|c|}{$\%$ Companies } & \multicolumn{1}{|c|}{$\begin{array}{c}\text { Companies that } \\
\text { offer training }\end{array}$} & $\begin{array}{c}\text { Companies that do } \\
\text { not offer training }\end{array}$ & $\begin{array}{c}\text { Hypothesis } \\
\text { testing }\end{array}$ \\
\hline With their own Internet domain & $81.0 \%$ & $61.9 \%$ & $\begin{array}{r}x^{2}=31,008 \\
\text { Sig }=0,000\end{array}$ \\
\hline $\begin{array}{l}\text { With a website on company } \\
\text { servers }\end{array}$ & $33.7 \%$ & $21.3 \%$ & $\begin{array}{r}x^{2}=32,538 \\
\text { Sig }=0,000\end{array}$ \\
\hline $\begin{array}{l}\text { With Internet sales to } \\
\text { companies (B2B) }\end{array}$ & $10.0 \%$ & $4.5 \%$ & $\begin{array}{c}X^{2}=32,684 \\
\text { Sig }=0,000\end{array}$ \\
\hline $\begin{array}{l}\text { With Internet sales to } \\
\text { consumers (B2C) }\end{array}$ & $6.8 \%$ & $1.9 \%$ & $\begin{array}{r}x^{2}=33,730 \\
\text { Sig }=0,000\end{array}$ \\
\hline Internet purchases & $34.7 \%$ & $15.5 \%$ & $\begin{array}{c}x^{2}=40,322 \\
\text { Sig }=0,000\end{array}$ \\
\hline
\end{tabular}

Table 6. Internet use. Companies that train employees compared to those that do not invest in training

An indicator of the intensity of Intensity use (USOSTECH) has been drawn up in which four levels of use are defined:

- Non-existent: the company does not even have its own domain.

- Low: the company has a website, but does not carry out any economic activity on the Internet.

- Medium: the company has a website and purchases from suppliers on the Internet.

- High: the company has an Internet domain and purchases and sells to other companies or end consumers on the Internet.

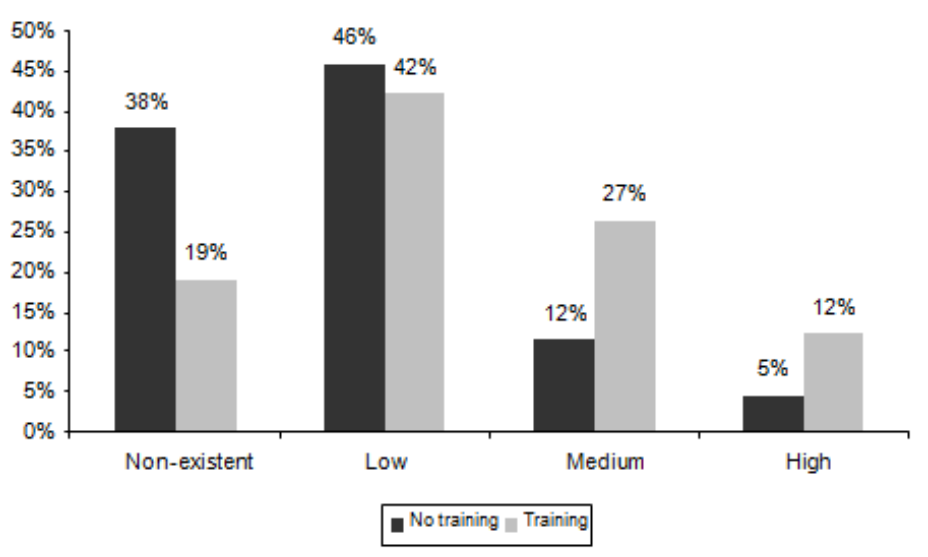

Figure 3. Intensity of Internet use. Training vs. no training 
To complete this descriptive analysis of research, development and innovation activity, we will briefly analyse the specific human capital dedicated to this kind of activity in organizations. Table 7 shows that research and development jobs in companies that do not offer training are practically non-existent. In contrast, companies that provide employee training do have this kind of staff. In some cases $(5.4 \%)$ they recruit staff with experience in this area.

\begin{tabular}{|l|r|r|r|}
\hline \multicolumn{1}{|c|}{ Companies } & $\begin{array}{c}\text { Companies that } \\
\text { offer training }\end{array}$ & $\begin{array}{c}\text { Companies that do } \\
\text { not offer training }\end{array}$ & $\begin{array}{c}\text { Hypothesis } \\
\text { testing }\end{array}$ \\
\hline $\begin{array}{l}\text { Employ recently graduated engineers } \\
\text { and degree holders }\end{array}$ & $17.9 \%$ & $3.0 \%$ & $\begin{array}{r}X^{2}=21,964 \\
\text { Sig }=0,000\end{array}$ \\
\hline $\begin{array}{l}\text { Recruit staff with research and } \\
\text { development experience in companies }\end{array}$ & $5.4 \%$ & $0.6 \%$ & $\begin{array}{r}X^{2}=6,692 \\
\text { Sig }=0,010\end{array}$ \\
\hline $\begin{array}{l}\text { Percentage of jobs in research and } \\
\text { development: }\end{array}$ & $3 \%$ & $0.3 \%$ & $\mathrm{~F}=24,910$ \\
$\mathrm{p}=0,000$
\end{tabular}

Table 7. Specific staff for research and development activities. Companies that train employees compared to those that do not invest in training

\section{Determining factors in corporate training}

In order to analyse the factors that determine the probability of a company investing in employee training, below we describe a discrete choice model with a dichotomous dependent variable. Specifically, we used a logistic regression model or logit. This model is a statistical technique that is suitable when the endogenous variable is categorical, and the exogenous variables are metric (Hair, Anderson, Tatham \& Black, 2004), as in our case. It is a technique that has been widely used in similar studies, such as Greenhalgh and Stewart (1987), Barron et al. (1987), Abellán et al. (1997), García-Espejo (1999) and Batalla-Busquets et al. (2010).

The logit model is expressed as follows:

$$
L_{i}=1 \mathrm{n}\left(\frac{P_{i}}{1-P_{i}}\right)=Z_{i}=\beta_{1}+\beta_{2} X_{2 i}+\ldots+\beta_{k} X_{k i}
$$


In this model, Pi takes the value of one if the company invests in training, and zero if the company does not invest in training. Therefore, if we apply these values to the logit model, the result is:

$L_{i}=\ln (1)=1 \mathrm{n}(+\infty)=+\infty \quad$ If the company invests in training

$L_{i}=\ln (0)=\ln (-\infty)=-\infty \quad$ If the company does not invest in training

Below, is a descriptive analysis to characterize the Spanish industrial sector according to investment/no investment in improving the training of employees.

After the descriptive analysis of the variables, we examine the results of the econometric analysis that illustrates the effects of these variables on the probability that employees are trained. The logistic regression model described below includes factors that significantly influence the probability that a company assumes the costs of employee training, compared to companies that do not train their employees. The model is specified as follows:

$$
L_{i}=1 \mathrm{n}\left(\frac{P_{i}}{1-P_{i}}\right)=Z_{i}=\beta_{2} \text { PERTOT }_{i}+\beta_{3} P R T P_{i}+\beta_{4} \text { PIL 0609 }_{i}+\beta_{5} \text { USOTECH }_{i}+\beta_{6} \text { INNOVEMPR }_{i}+\beta_{7} \text { AID }_{i}
$$

Where:

$L_{i}$ is the logistic function associated with the probability of a company paying for employee training $\left(P_{i}=1\right)$ or the lack of company training $\left(P_{i}=0\right)$; PERTOT $\boldsymbol{i}$ is the total number of staff in the company; $\boldsymbol{P R T P} \boldsymbol{P}_{\boldsymbol{i}}$ is the productivity per employee in GVA; $\boldsymbol{P I L 0 6 0 9}$ is the proportion of engineers and graduates in the period 2006-2009; USOSTECH $\boldsymbol{H}_{\boldsymbol{i}}$ is an indicator of the use of the Internet; INNOVEMPR is a binary variable that indicates whether a company has

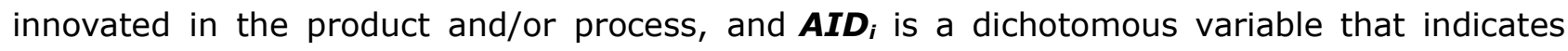
whether the company has carried out research and development activities.

As can be seen, this model is comprised of six statistically significant exogenous variables (total staff, productivity per employee, proportion of engineers and degree holders, level of Internet use, business innovation, and research and development activities). The degree of correlation between the variables, which was no higher than $40 \%$ in any of the cases, is shown in Table 8. The goodness of fit of the model is acceptable, as the overall predictive capability of the model is $90 \%$, the Cox-Snell $R^{2}$ is $57.7 \%$ and the Nagelkerke R2 is $76.9 \%$ (see Table 9 ). 


\begin{tabular}{|c|c|c|c|c|c|c|c|}
\hline & $L_{i}$ & PERTOT & PRTP & PIL0609 & USOSTECH & INNOVEMPR & AID \\
\hline$L_{i}$ & 1 & & & & & & \\
\hline PERTOT & $0.098 * *$ & 1 & & & & & \\
\hline PRTP & $0.137 * *$ & $0.149 * *$ & 1 & & & & \\
\hline PIL0609 & $0.124 * *$ & $0.164 * *$ & $0.306 * *$ & 1 & & & \\
\hline USOSTECH & $0.116 * *$ & $0.140 * *$ & $0.151 * *$ & $0.157 * *$ & 1 & & \\
\hline INNOVEMPR & $0.164 * *$ & $0.190 * *$ & $0.149 * *$ & $0.179 * *$ & $0.211 * *$ & 1 & \\
\hline AID & $0.182 * *$ & $0.310 * *$ & $0.203^{* *}$ & $0.328 * *$ & $0.260 * *$ & $0.426 * *$ & 1 \\
\hline
\end{tabular}

Table 8. Correlation matrix 2009

All the variables have a positive effect on the probability of companies paying for training. In particular, there was a higher odds-ratio for the three variables related to the use of technologies and corporate innovation. In other words, companies that carry out research and development activities and/or use the Internet in a more sophisticated way and/or innovate in the product or process have a greater likelihood of investing in employee training. In fact, the use of increasingly specialized technologies requires very specific knowledge and skills that are not easy to find in the labour market. Consequently, training should help employees to gain these skills (Castany, 2008).

Likewise, the size of the company has a positive influence on the probability of training, as described in the ample scientific literature. Among other reasons, this is because

- larger companies have a greater capacity to substitute employees who are training,

- they obtain economies of scale with the training, and

- they have more opportunities to offer a more attractive career associated with the employee's qualification (Holtmann \& Idson, 1991; Black et al., 1999; Crespo \& Sanz, 2000; Caparrós et al., 2005; Castany, 2008).

The gross value added per employee is positively correlated with the probability of training. This relation is due to the fact that companies that bring greater added value to the production process require staff with a higher level of training (Batalla-Busquets et al., 2010). Finally, the proportion of engineers and degree holders is also positively related to continuing vocational training. Good prior training of the employee is a guarantee of good returns on investment in training (Harris, 1999). In addition, better trained employees are more likely to take on greater responsibilities in the company, which are often closely linked to a training process (Peraita, 2000; García Moreno et al., 2007). 


\begin{tabular}{|l|r|r|r|r|r|}
\cline { 2 - 6 } \multicolumn{1}{c|}{} & $\boldsymbol{\beta}$ & \multicolumn{1}{c|}{ TE } & \multicolumn{1}{c|}{ Wald } & \multicolumn{1}{c|}{ Sig } & \multicolumn{1}{c|}{ Odds-ratio } \\
\hline PERTOT & 0.006 & 0.002 & 10.265 & 0.001 & 1.006 \\
\hline PRTP & 0.019 & 0.005 & 16.394 & 0.000 & 1.020 \\
\hline PIL0609 & 0.040 & 0.021 & 3.777 & 0.052 & 1.041 \\
\hline USOSTECH & 0.248 & 0.108 & 5.311 & 0.021 & 1.282 \\
\hline INNOVEMPR & 0.573 & 0.268 & 4.584 & 0.032 & 1.773 \\
\hline AID & 0.473 & 0.145 & 10.688 & 0.001 & 1.605 \\
\hline
\end{tabular}

Cox-Snell $R^{2}: 0.577 ;$ Nagelkerke $R^{2}: 0.769 ; X^{2}=12,901 ; \mathrm{Sig}=0.115$

PERTOT: Total staff; PRTP: Productivity per employee (value added);PIL0609: proportion of engineers and graduates; USOSTECH: Level of Internet use; INNOVEMPR: Corporate innovation; AID: Research and development activities

Table 9. Model of the probability that companies pay for training. Logit model; dependent variable: training paid for by the company or no training

\section{Conclusions}

In a context such as the current one, in which job are constantly being lost and companies are folding due to a loss of international competitiveness among Spanish companies and the collapse of much of the domestic market, human capital development is seen as one of the few options that could change the course of the Spanish economy.

The results obtained in this study show that the probability of companies investing in employee training depends on the total number of company employees, the productivity per employee, the level of qualification of employees, the level of Internet use, business innovation, and research and development activities. This study indicates that the Spanish industrial sector does not have ideal characteristics for investment in employee training, according to international literature, as many companies are small, their employees have a low level of qualifications, and there is little innovation and research activity.

Consequently, the gap has not been closed between large competitive companies that use digital resource intensively, are innovative, and have highly qualified human capital, and the remaining small and medium-sized companies (Batalla-Busquets et al., 2010). This confirms a statement made by Crespo and Sanz (2000): the mass introduction of digital technologies into companies added to the lower probability of training for employees with a lower level of studies could lead to the practical exclusion from continuing vocational training of the least qualified employees, with the resulting loss of incentives for a company to train them.

The Spanish industrial sector is reasonably well-equipped digitally. However, although most companies have a website, the use of this platform is negligible. When the business organization has not been globalized or digitalized, a good Internet infrastructure becomes a cost rather than a business opportunity. Therefore, an investment in employee training is required to maximize the Internet opportunities. In addition, as indicated by Huergo and 
Moreno (2004), the Spanish industry encounters difficulties in turning investment in innovation into tangible results that can be used to improve process and products, and consequently increase the competitiveness of the industrial sector.

The main limitation of this study is sample bias, as most of the sample is comprised of large companies and there is only a small percentage of small and medium-sized companies, when these represent almost $85 \%$ of the Spanish industrial sector. A second limitation of the study is in the concept of company training that does not involve an associated cost. In this case, it is difficult to discern the quality, intensity and returns on this training.

\section{Acknowledgments}

This study is the result of work carried out by the two authors during academic year 20112012, as part of the Internet Interdisciplinary Institute's (IN3) research residency programme. We would like to sincerely thank the director of this programme, PhD Manuel Castells and the vice-directors, PhD Meritxell Roca Sales and PhD Josep Lladós Masllorens, for the facilities they provided, the excellent space in the IN3, and the funding of our project.

\section{References}

ABELLÁN, C.; FELGUEROSO, F.; LORENCES, J. (1997). La negociación colectiva en España: Una reforma pendiente. Papeles de Economía Española, 72: 250-260.

ALBA-RAMÍREZ, A. (1994). Formal Training, Temporary Contracts, Productivity and Wages in Spain. Oxford Bulletin of Economics and Statistics, 56(2): 151-170.

http://dx.doi.org/10.1111/j.1468-0084.1994.mp56002003.x

ALBERT, C.; GARCÍA-SERRANO, C.; HERNANZ, V. (2005). Firm-provided training and temporary contracts. Spanish Economic Review, 7: 67-88. http://dx.doi.org/10.1007/s10108-0040087-1

ALTONJI, J.; SPLETZER, J. (1991). Worker characteristics, job characteristics, and the receipt of on-the-job training. Industrial and Labor Relations Review, 45(1): 58-79. http://dx.doi.org/10.2307/2524702

ARULAMPALAM, W.; BOOTH, A.L. (1998). Training and labour market flexibility: Is there a trade-off?. British Journal of Industrial Relations, 36(4): 521-536. 
BARRON, J.M.; BLACK, D.A,; LOEWENSTEIN, M.A. (1987). Employer Size: The Implications for Search, Training, Capital Investment, Starting Wages and, Wage Growth. Journal of Labor Economics, 5(1): 76-89. http://dx.doi.org/10.1086/298138

BATALLA-BUSQUETS, JM.; MARTÍNEZ-ARGÜELLES, M.J.; VILASECA, J. (2010). La decisión empresarial de invertir en la mejora de la formación de los trabajadores: Factores determinantes para el tejido empresarial catalán. Regional and Sectoral Economic Studies, 10(3): $93-116$

BECKER, G.S. (1964). Human Capital. A Theoretical and Empirical Analysis, with Special Reference to Education (2nd Ed. (1975)). Londres: The University of Chicago Press.

BISHOP, J. (1994). The impact of previous training on productivity wages. In L. Lynch (Ed.), Training and the Private Sector. International Comparisons (Chapter 6). Londres: Chicago University Press.

BISHOP, J. (1996). What we know about employer-provider training: A review of literature. Center for Advanced Human Resources Studies, Working Paper Series 96-09, NY: Cornell University, Ithaca.

BLACK, D.; NOEL, B.; WANG, Z. (1999). On-the-job training, establishment size, and firm size: Evidence for economies of scale in the production of human capital. Southern Economic Journal, 66(1): 82-100. http://dx.doi.org/10.2307/1060836

BRESNAHAN, T.F.; BRYNJOLFSSON, E.; HITT, L.M. (2002). Information technology, workplace organization, and the demand for skilled labor: Firm-level evidence. MIT Sloan School Working Paper, 154. http://dx.doi.org/10.1162/003355302753399526

BRYNJOLFSSON, E.; HITT, L. (2003). Computing Productivity: Firm-Level Evidence. The Review of Economics and Statistics, MIT Press, 85(4): 793-808.

http://dx.doi.org/10.1162/003465303772815736

CAPARRÓS, A; NAVARRO, M.L.; RUEDA, M.F. (2004). Efectos de la temporalidad sobre la formación recibida durante el empleo. Cuadernos de Economía, 27: 51-74.

CAPARRÓS, A; NAVARRO, M.L.; RUEDA, M.F. (2005). Determinantes de la formación en la empresa. Actas de las XIV Jornadas de la Asociación de Economía de la Educación (AEDE), 171-185. Asociación de Economía de la Educación. Oviedo.

CARNOY, M. (2001). El trabajo flexible en la era de la información. Madrid: Alianza Editorial.

CASTANY, L. (2008). The role of firm size in the firms' training decisions: the Spanish case. Research Institute of Applied Economics. Working Paper 2008/08. Universitat de Barcelona (IREA). Barcelona. 
CASTELLS, M. (2003). La era de la información: Economía, sociedad y cultura. Vol. 1: La sociedad en red (2nd Ed.). Madrid: Alianza Editorial.

COETZER, A.; PERRY, M. (2008). Factors influencing employee learning in small businesses. Education + Training, 50(8): 648-660.

CRESPO, J.; SANZ, I. (2000). La Formación Continua en España: implicaciones de política económica. Papeles de Economía Española, 86: 280-294.

DE GRIP, A.; SAUERMANN, J. (2013). The effect of training on productivity: The transfer of onthe-job training from the perspective of economics. Educational Research Review, 8: 28-36. http://dx.doi.org/10.1016/j.edurev.2012.05.005

DIÉGUEZ, M.I.; SINDE, A.I. (2004). Determinantes de la formación en empresas adoptantes de nuevas tecnologías de fabricación avanzada. Investigaciones Europeas de Dirección y Economía de la Empresa, 10(2): 115-130.

DUNCAN, G.J.; HOFFMAN, S. (1979). On-the-Job Training and Earnings Differences by Race and Sex. The Review of Economics and Statistics, 61(4): 594-603.

http://dx.doi.org/10.2307/1935790

ESCARDÍBUL, J.O.; OROVAL, E.; AFCHA, S. (2007). El procés de formació a l'empresa. Una anàlisi en grans organitzacions de Catalunya. Nota d'economia, 89: 69-84.

FAN, C.S.; WEI, X. (2010). Training and worker effort: a signalling perspective. The Canadian Journal of Economics, 43(2): 604-621. http://dx.doi.org/10.1111/j.1540-5982.2010.01585.x

FUNDACIÓN TRIPARTITA (2012). Memoria 2012. Digital single edition, available online in: www.fundaciontripartita.org. Fundación Tripartita para la formación en el empleo.

GARCÍA DELGADO, J.L. (2003). Lecciones de economía española (6th. Ed.). Madrid: ThomsonCivitas.

GARCÍA-ESPEJO, I. (1999). Formación en el trabajo y movilidad laboral. Papers, 59: 195-219.

GARCÍA-MORENO, S.; GUERRAS, L.A.; RICO, M.G. (2007). La decisión de invertir en la formación de los empleados. Un análisis en la empresa industrial española. In J.C. Ayala (Coordinador), Conocimiento, innovación y emprendedores: camino al futuro (pages 36943709). Logroño: Ediciones Universidad de la Rioja.

GREENHALGH，C.; STEWART, M. (1987). The effects and determinants of training. Oxford Bulletin of Economics and Statistics, 49(2): 171-190. http://dx.doi.org/10.1111/j.14680084.1987.mp49002001.x

HAIR, J.F.; ANDERSON, R.E.; TATHAM, R.L.; BLACK, W.C. (2004). Análisis Multivariante. Madrid: Pearson, Prentice Hall. 
HAELERMANS, C.; BORGHANS, L. (2012). Wage Effects of On-the-Job Training: A MetaAnalysis. British Journal of Industrial Relations, 50(3): 502-528. http://dx.doi.org/10.1111/j.14678543.2012.00890.x

HARRIS, R. (1999). The determinants of work-related training in Britain in 1995 and the implications of employer size. Applied Economics, 31: 451-463.

http://dx.doi.org/10.1080/000368499324165

HASHIMOTO, M. (1979). Bonus payments, on the job training and life time employment in Japan. Journal of Political Economy, 87: 1086-1104. http://dx.doi.org/10.1086/260813

HOLTMANN, A.; IDSON, T. (1991). Employer size and on-the-job training decisions. Southern Economic Journal, 58(2): 339-355. http://dx.doi.org/10.2307/1060178

HUERGO, E.; MORENO, L. (2004). La innovación y el crecimiento de la productividad en España. Ekonomiaz, 56: 208-231.

JEON, K.S.; KIM, K.N. (2012). How do organizational and task factors influence informal learning in the workplace?. Human Resource Development International, 15(2):209-226. http://dx.doi.org/10.1080/13678868.2011.647463

JOHNSON, C. (1982). MITI and the Japanese Miracle: The Growth of Industrial Policy, 19251975. Stanford: Stanford University Press.

JONKER, N.; DE GRIP, A. (1999). Do employees with flexible contracts receive less training?. Working paper ROA_RM / 1E. Research Centre for Education and labour Market. Maastricht University.

LYNCH, L. (1992). Private-sector Training and the Earnings of Young Workers. American Economic Review, 82(1): 299-312.

LYNCH, L. (1994). Training and the private sector. International comparisons. Londres: The University of Chicago Press. http://dx.doi.org/10.7208/chicago/9780226498157.001.0001

LYNCH, L.; BLACK, S. (1995). Beyond the incidence of training: Evidence from a national employers survey. National Bureau of Economic Research. Working paper, 5231, Cambridge.

MINCER, J.; POLACHEK, S. (1974). Family investments in human capital: Earnings of women. Journal of Political Economy, 82(2), supplement S76-S108. http://dx.doi.org/10.1086/260293

MINISTERIO DE EDUCACIÓN, CULTURA Y DEPORTES (2013). Panorama de la educación. Indicadores de la OCDE 2013. Informe español. Madrid: Instituto Nacional de Evaluación Educativa.

MONREAL, J. (2004). Formación y cultura empresarial en la empresa española. Madrid: Ed. Thomson Civitas. 
OECD (1999). Tableau de bord de l'OCDE de la Sciencie, Technologie et de l'Industrie: Mesurer les économiesfondées sur le savoir. Paris: OCDE.

OECD (2010). Learning for jobs. Paris: OECD. http://dx.doi.org/10.1787/9789264087460-en

OI, W. (1983). Heterogeneous Firms and the Organization of Production. Economic Inquiry, 21: 147-171. http://dx.doi.org/10.1111/j.1465-7295.1983.tb00623.x

OOSTERBEEK, H. (1996). A Decomposition of Training Probabilities. Applied Economics, 28: 799-805. http://dx.doi.org/10.1080/000368496328236

PERAITA, C. (2000). Características de la formación de la empresa española. Papeles de Economía Española, 86: 295-307.

PFEFfer, J. (1998). The Human Equation: Building Profits by Putting People First. Cambridge: Harvard Business SchoolPress.

PINEDA HERRERO, P. (2007). La formación continua en España: Balance y retos de futuro. RELIEVE, 13 (1): 43-65.

PIORE, M.; SABEL, C. (1984). The Second Industrial Divide. New York: Basic Books.

PLANAS, J.; PLASSARD, J.M. (2000). La inversión en formación inicial como condición previa para las inversiones en formación a lo largo de la vida. Efficacité versus équité en économie sociales. Paris: Ediciones L'Harmattan

SCHULTZ, T.W. (1961). Investment in Human Capital. The American Economic Review, LI(1): 1-17.

TUGORES, M.; ALBA-RAMÍREZ, A. (2002). Estudio microeconómico sobre la formación continua en España. 1992-2002. Revista de Economía Industrial, 348: 77-94.

TURCOTTE, J.; LÉONARD, A.; MONTMARQUETTE, C. (2003). New Evidence on the Determinants of Training in Canadian Business Locations. The Evolving Workplace Series, Statistics Canada, 71-584-MPE, 5.

VILA, L; GARCÍA-MORA, B. (2005). Education and the determinants of job satisfaction. Education Economics, 13(4): 409-425. http://dx.doi.org/10.1080/09645290500251730

Intangible Capital, 2015 (www.intangiblecapital.org) 